\title{
Thermodynamic Studies of the Liquid Ni-Pd Alloys by Mass Spectrometric and Solid State EMF Measurements
}

\author{
By Toshio Oishi*, Seiji Nishi** and Katsutoshi Ono*
}

\begin{abstract}
The activities and the partial molar heats of mixing were determined in the Ni-Pd system using a Knudsen cell and a quadrupole mass spectrometer. The activity of nickel in this system was measured by means of a zirconia solid oxide galvanic cell, $\mathrm{Pt}$, air $/ \mathrm{ZrO}_{2}+\mathrm{CaO} / \mathrm{Ni}-\mathrm{Pd}(1), \mathrm{NiO} / \mathrm{Cr}_{2} \mathrm{O}_{3}$ or $\mathrm{LaCrO}_{3}, \mathrm{Pt}$.

Although the activities of nickel obtained by the emf measurements showed slightly lower values over the entire composition range than those obtained by mass spectrometry, both results were in close agreement and exhibited negative deviations from Raoult's law. The activity coefficients of nickel and palladium at infinite dilution at $1833 \mathrm{~K}$ were also determined.
\end{abstract}

(Received November 9, 1985)

Keywords: thermodynamics, activity measurement, nickel-palladium system, mass spectrometry, emf measurement, zirconia solid electrolyte

\section{Introduction}

The vapour pressure and/or the solid state emf techniques have been generally employed for the measurement of the thermodynamic properties of liquid metallic solutions at higher temperatures, at which the chloride electrolyte cell can not be used.

One effective approach for the vapour pressure measurements is the use of a mass spectrometer. Belton and Fruehan ${ }^{(1)}$ introduced a useful method for determining the activities and the partial molar heats of mixing with the Knudsen cell-mass spectrometer combination. Their method consists of measuring the ratio of ion currents produced by two monatomic vapours above a binary alloy and substituting the ratio for the activity term in the Gibbs-Duhem relation:

$\ln \gamma_{1}=-\int_{N_{1}=1}^{N_{1}=N_{1}} N_{2} \mathrm{~d}\left[\ln \left(I_{2}^{+} / I_{1}^{+}\right)-\ln \left(N_{2} / N_{1}\right)\right]$,

* Department of Metallurgy, Kyoto University, Sakyoku, Kyoto 606, Japan.

** Graduate Student, Kyoto University, Kyoto. Present address: Central Research Lab., Kobe Steel Co., Wakinohama, Fukiai-ku, Kobe 651, Japan. $\ln \gamma_{2}=\int_{N_{2}=1}^{N_{2}=N_{2}} N_{1} \mathrm{~d}\left[\ln \left(I_{2}^{+} / I_{1}^{+}\right)-\ln \left(N_{2} / N_{1}\right)\right]$

and

$$
\begin{aligned}
& \Delta \bar{H}_{1}=-R \int_{N_{1}=1}^{N_{1}=N_{1}} N_{2} \mathrm{~d}\left[\frac{\mathrm{d} \ln \left(I_{2}^{+} / I_{1}^{+}\right)}{\mathrm{d}(1 / T)}\right], \\
& \Delta \bar{H}_{2}=R \int_{N_{2}=1}^{N_{2}=N_{2}} N_{1} \mathrm{~d}\left[\frac{\mathrm{d} \ln \left(I_{2}^{+} / I_{1}^{+}\right)}{\mathrm{d}(l / T)}\right]
\end{aligned}
$$

where $\gamma_{1}$ is the activity coefficient of the component 1 , defined as $\gamma_{1}=a_{1} / N_{1} . a_{1}, N_{1}$ and $\Delta \bar{H}_{1}$ are the activity, the atom fraction and the partial molar heat of mixing of the component 1 , respectively, and $\mathrm{I}^{+}$is the ion current of a mass filter proportional to the partial pressure of the components in the Knudsen cell containing the liquid alloy.

In the present study, mass spectrometry was used to investigate the thermodynamic properties in the liquid Ni-Pd system. Subsequently, the activity of nickel in $\mathrm{Ni}-\mathrm{Pd}$ alloys was measured by using a zirconia solid electrolyte galvanic cell to assess the reliability of the activity values obtained by the mass spectrometric method. 


\section{Experimental}

\section{Mass spectrometric measurements}

A NEVA quadrupole mass filter, type NAG531, was combined with a high temperature vacuum furnace with a cylindrical tantalum heater $20 \mathrm{~mm}$ in diameter and $100 \mathrm{~mm}$ long. A schematic diagram of the mass filter and details of the experimental methods have been given in a previous paper ${ }^{(2)}$. Briefly, mass peaks 58 and 106 were used for nickel and palladium, respectively, and an ionization potential of 21 $\mathrm{eV}$ was employed. The $\mathrm{Ni}-\mathrm{Pd}$ alloys were prepared in situ by melting about $1 \mathrm{~g}$ of the component metals, the purities of which were: $\mathrm{Ni}, 99.5 \%$ and $\mathrm{Pd}, 99.99 \%$. The alumina Knudsen cells used in the experiment were 11 $\mathrm{mm}$ in o.d., $9 \mathrm{~mm}$ in i.d. and $7 \mathrm{~mm}$ in height, and the lid had a thickness of $0.5 \mathrm{~mm}$ and a knife-edged orifice with diameter of $0.5 \mathrm{~mm}$.

\section{Emf measurements}

In the present investigation, electromotive force measurements were made on a cell of the type,

$$
\begin{gathered}
\mathrm{Pt}, \text { air } / \mathrm{ZrO}_{2}+\mathrm{CaO} / \mathrm{Ni}(1) \text { or } \mathrm{Ni}-\mathrm{Pd}(1), \\
\mathrm{NiO} / \mathrm{Cr}_{2} \mathrm{O}_{3} \text { or } \mathrm{LaCrO}_{3} \text {, Pt. }
\end{gathered}
$$

A schematic diagram of the cell arrangement is shown in Fig. 1. $\mathrm{ZrO}_{2}+11$ mole pct $\mathrm{CaO}(10$ $\mathrm{mm}$ in o.d., $7 \mathrm{~mm}$ in i.d. and $100 \mathrm{~mm}$ long), made by Nippon Kagaku Togyo Co., was used both as a solid electrolyte and a crucible. The alloys were made beforehand by melting about $3 \mathrm{~g}$ of component metals in a high-frequency induction furnace. A small amount of nickel oxide powder was added to the Ni-Pd alloys in a zirconia electrolyte tube. This tube was attached to a tight-fitting alumina tube using zirconia cement. The upper end of the alumina tube was sealed with a rubber cap. For the air reference electrode, a platinum wire was used as an electrical lead. Platinum paste was applied to the outside of the electrolyte over a length of about $20 \mathrm{~mm}$ from the bottom, and the platinum wire was wound on the patinum paste.

Two kinds of electrode leads $\left(\mathrm{Cr}_{2} \mathrm{O}_{3}\right.$ and

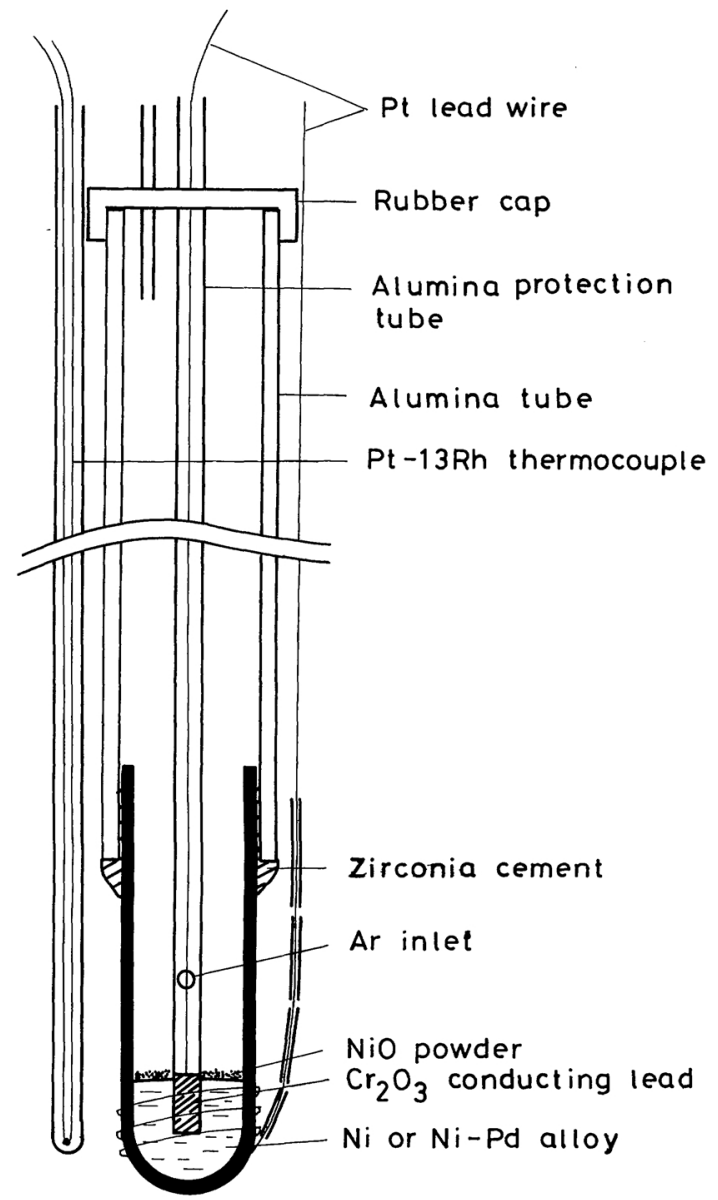

Fig. 1 Cell used to measure emf in the liquid Ni-Pd alloys.

$\mathrm{LaCrO}_{3}$ ) were tested for the liquid alloys. 1) After mixing with a small amount of water, $\mathrm{Cr}_{2} \mathrm{O}_{3}$ powder and a platinum wire were placed into an alumina protection tube (shown in Fig. 1). 2) $\mathrm{A} \mathrm{LaCrO}_{3}$ electrode lead $2 \mathrm{~mm}$ in diameter and $30 \mathrm{~mm}$ long was placed in the end of an alumina tube, electrical contact being made via a platinum lead wound round one end. The tube was sealed with zirconia cement to prevent corrosion of platinum by the liquid metal (not shown in Fig. 1). This alumina tube has a small hole about $1 \mathrm{~mm}$ in diameter at a position about $100 \mathrm{~mm}$ from the lower end. High purity argon was introduced through this hole during the experiment.

The cell was heated slowly to a desired temperature under a stream of argon. Initial 
equilibrium of each experimental run was generally attained in several hours after reaching the desired temperature. Emf measurements were made at ascending and descending temperatures in the range from 1673 to $1823 \mathrm{~K}$ with an accuracy of $\pm 0.1 \mathrm{mV}$ by a digital multimeter with an input impedance of $10 \mathrm{M} \Omega$. The furnace used was of a silicon carbide resistance type and its temperature was controlled within an error of $\pm 1 \mathrm{~K}$.

\section{Results and Discussion}

\section{Mass spectrometric measurements}

The experimental values of the ion current ratios are presented in Fig. 2 as values of $\ln \left(I_{\mathrm{Ni}}^{+} / I_{\mathrm{Pd}}^{+}\right)$vs. $1 / T$. The relationship between $\ln \left(I_{\mathrm{Ni}}^{+} / I_{\mathrm{Pd}}^{+}\right)$and $1 / T$ was linear for all composi-

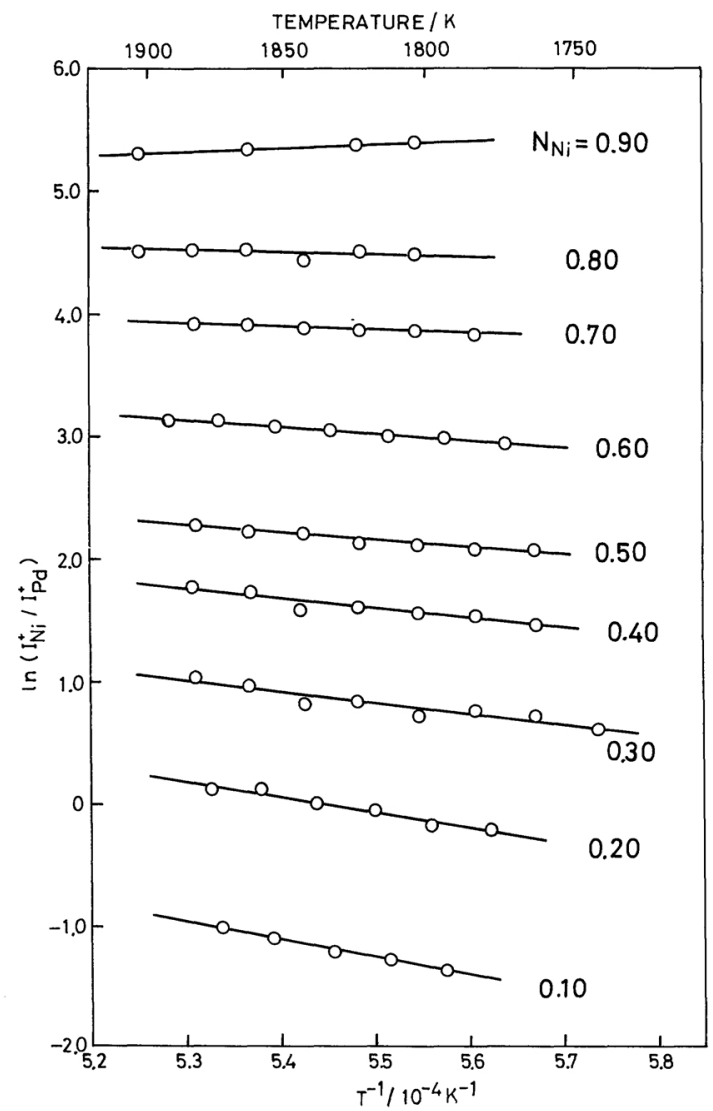

Fig. 2 Experimental values of the ion current ratio for the $\mathrm{Ni}-\mathrm{Pd}$ system.

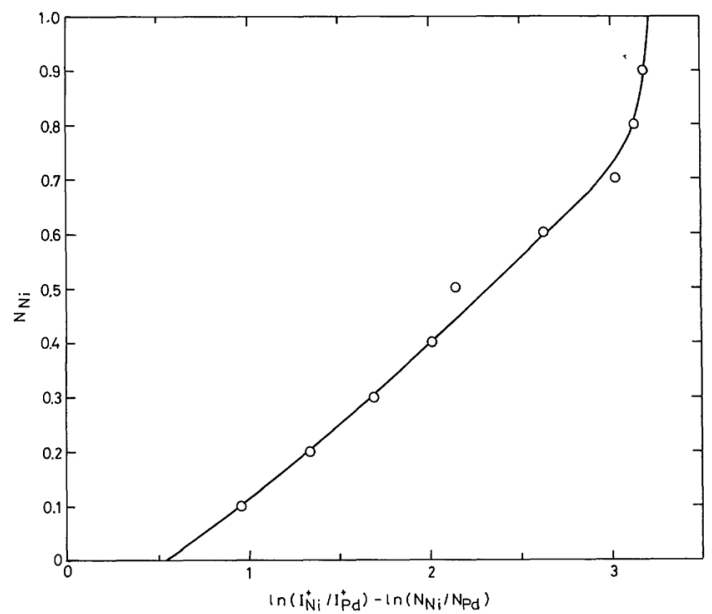

Fig. 3 Integration plot for activity coefficients in the liquid $\mathrm{Ni}-\mathrm{Pd}$ system at $1833 \mathrm{~K}$.

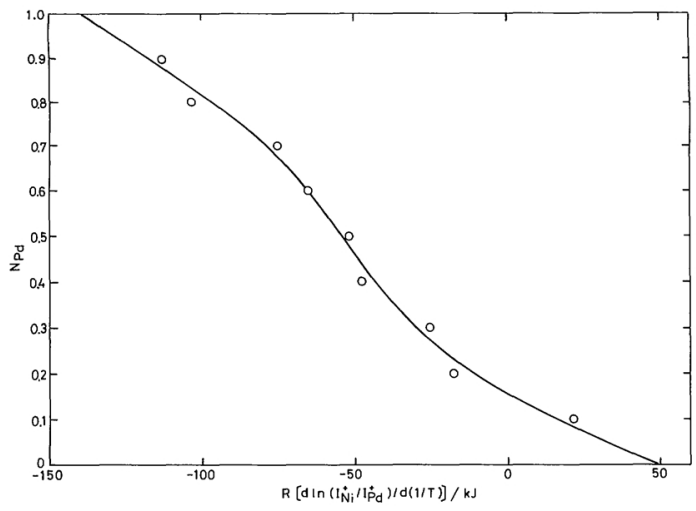

Fig. 4 Integration plot for the partial molar heats of mixing in the liquid Ni-Pd system.

tions. From the derived slopes and the values for $\ln \left(I_{\mathrm{Ni}}^{+} / I_{\mathrm{Pd}}^{+}\right)$interpolated at $1833 \mathrm{~K}$, the values of $\ln \left(I_{\mathrm{Ni}}^{+} \cdot N_{\mathrm{Pd}} / I_{\mathrm{Pd}}^{+} \cdot N_{\mathrm{Ni}}\right)$ and $R\left[\operatorname{dln}\left(I_{\mathrm{Ni}}^{+} /\right.\right.$ $\left.\left.I_{\mathrm{Pd}}^{+}\right) / \mathrm{d}(1 / T)\right]$ were calculated. The results are shown as a function of composition in Figs. 3 and 4 , respectively.

Using eqs. (1) and (2), and the integrated areas under the curve in Fig. 3, the values of $\gamma_{\mathrm{Ni}}$ and $\gamma_{\mathrm{Pd}}$ were calculated at $1833 \mathrm{~K}$. The results are shown in Table 1. The activities of nickel and palladium are shown in Fig. 5. These activities showed negative deviations over the entire composition range, and the activity coefficients at infinite dilution were obtained: $\gamma_{\mathrm{Ni}}^{0}=0.188$ and $\gamma_{\mathrm{Pd}}^{0}=0.367$.

The partial molar heats of mixing were 
Table 1 Activity coefficient for the Ni-Pd system at 1833 K.

\begin{tabular}{ccc}
\hline \hline$N_{\mathrm{Ni}}$ & $\gamma_{\mathrm{Ni}}$ & $\gamma_{\mathrm{Pd}}$ \\
\hline 0.00 & 0.188 & 1.000 \\
0.10 & 0.289 & 0.978 \\
0.20 & 0.400 & 0.923 \\
0.30 & 0.513 & 0.850 \\
0.40 & 0.632 & 0.759 \\
0.50 & 0.752 & 0.659 \\
0.60 & 0.857 & 0.561 \\
0.70 & 0.940 & 0.473 \\
0.80 & 0.987 & 0.409 \\
0.90 & 0.998 & 0.384 \\
1.00 & 1.000 & 0.367 \\
\hline \hline
\end{tabular}

calculated from eqs. (3) and (4), and the integrated areas under the curve in Fig. 4. Figure 6 shows that this system has a negative enthalpy of mixing, and the minimum value of $\Delta H$ is about $-19 \mathrm{~kJ} / \mathrm{mol}$.

\section{Emf measurements}

Figure 7 shows the temperature dependences of emf of the cell (I) for pure nickel and seven different Ni-Pd liquid alloys. The relationship between the emf and temperature was linear for all compositions. From the emf for $\mathrm{Ni}-$ $\mathrm{NiO}$ equilibrium in Fig. 7, the standard free energy of formation of $\mathrm{NiO}$ in the temperature range $1723-1823 \mathrm{~K}$ was obtained as a function af temperature,

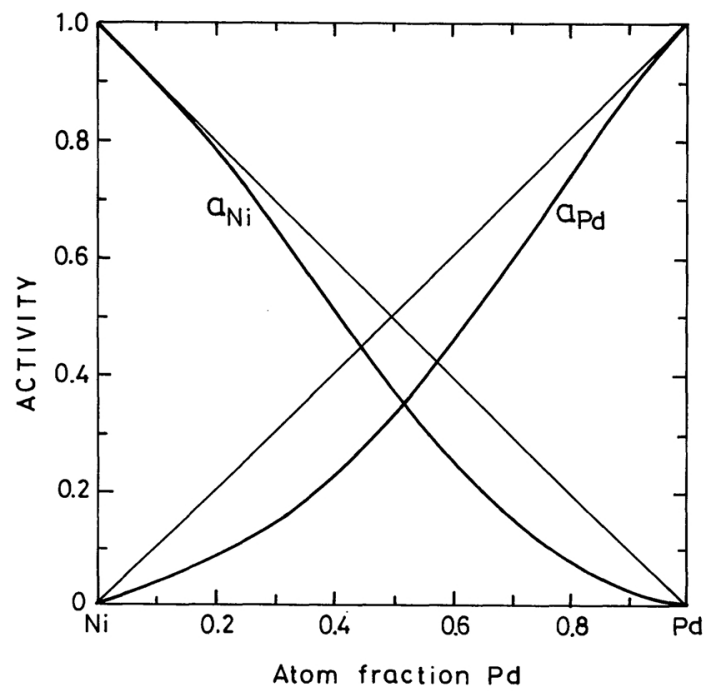

Fig. 5 Activities for the $\mathrm{Ni}-\mathrm{Pd}$ system at $1833 \mathrm{~K}$. (mass spectrometry)

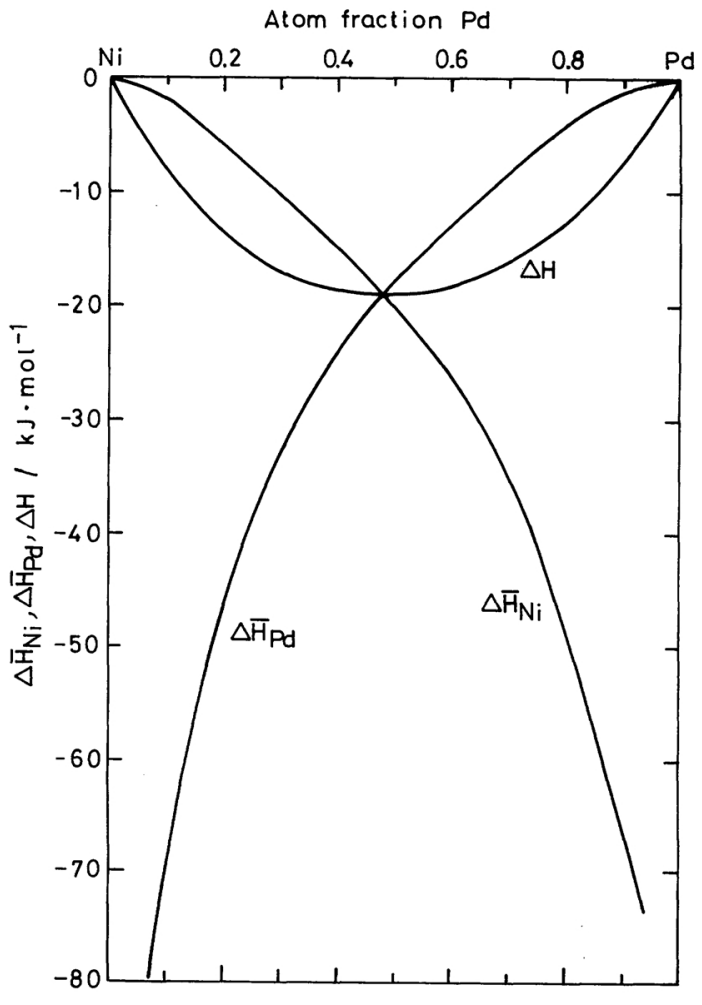

Fig. 6 Integral and partial molar heats of mixing for the Ni-Pd system.

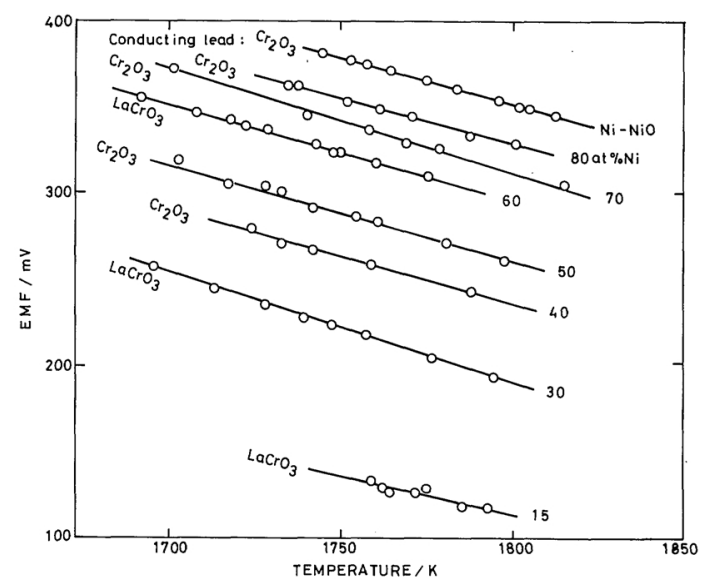

Fig. 7 Emf of the cell; $\mathrm{Pt}$, air $/ \mathrm{ZrO}_{2}+\mathrm{CaO} / \mathrm{Ni}(1)$ or $\mathrm{Ni}-$ $\mathrm{Pd}(1), \mathrm{NiO}(\mathrm{s}) / \mathrm{Cr}_{2} \mathrm{O}_{3}$ or $\mathrm{LaCrO}_{3}$, Pt.

$$
\Delta G_{\mathrm{NiO}}^{\circ}\left(\mathrm{kJ} \cdot \mathrm{mol}^{-1}\right)=-257900+99.14 T .
$$

The activities of nickel in the liquid $\mathrm{Ni}-\mathrm{Pd}$ alloys were calculated from the following equation, 


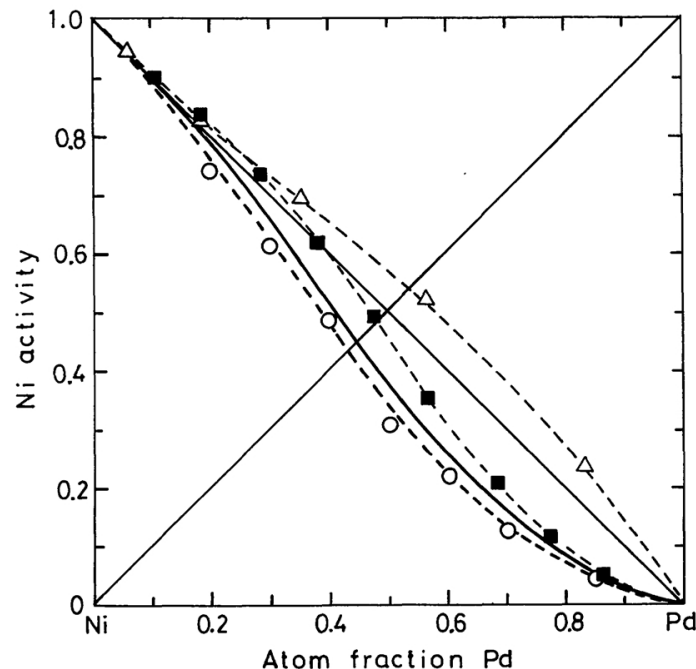

Fig. 8 Summary of results for the activity of nickel in the liquid $\mathrm{Ni}-\mathrm{Pd}$ alloys. - - this study (mass spectrometry, $1833 \mathrm{~K})$; --- $\bigcirc---$, this study (emf, $1773 \mathrm{~K}$ ); $--\triangle---$, Timofeev et $a l .{ }^{(3)}(\mathrm{emf}, 1873 \mathrm{~K}) ;---\square--$ Bidwell and Speiser ${ }^{(4)}$ (emf, $1473 \mathrm{~K}$, solid region).

$$
2\left(E_{\mathrm{Ni}-\mathrm{Pd}}-E_{\mathrm{Ni}}\right) F=R T \ln a_{\mathrm{Ni}},
$$

where $E$ is the electromotive force of the cell (I). Figure 8 shows the activities of nickel in the liquid $\mathrm{Ni}-\mathrm{Pd}$ alloys at $1773 \mathrm{~K}$ obtained from emf measurements together with the results obtained by Timofeev et al. ${ }^{(3)}$. and the present results by mass spectrometry as well as the results in the solid alloys presented by Bidwell et al. ${ }^{(4)}$ The activities of nickel obtained by the emf measurements show slightly lower values over the entire composition range than those by mass spectrometry. This difference in the values seems to exceed that due to the temperature difference. However, a similar tendency can be seen between the two.

In the emf measurements, pure nickel or NiPd alloys were equilibrated with solid nickel oxide. According to the literature ${ }^{(5)(6)}$, pure liquid nickel in equilibrium with $\mathrm{NiO}(\mathrm{s})$ dissolves 0.4-0.45 mass pet oxygen at $1773 \mathrm{~K}$. Unfortunately, there are no data on the solubility of oxygen in liquid palladium. However, it seems that the solubility of oxygen in the liquid $\mathrm{Ni}$ $\mathrm{Pd}$ alloys is not so high as that of in pure liquid nickel under the oxygen partial pressure studied in this experiment. For this reason, the oxygen contents in the liquid alloys were neglected in the calculation of nickel activity. Timofeev et al. also used the zirconia solid electrolyte to measure the nickel activity in the liquid Ni-Pd alloys. However, their results show a positive deviation from Raoult's law and differ from the present results. This difference can not be explained at this stage.

\section{Summary}

The activities and the partial molar heats of mixing were determined in the liquid $\mathrm{Ni}-\mathrm{Pd}$ system with the combination of a Knudsen cell and a quadrupole mass spectrometer. The activity of nickel in this system was also measured by means of the zirconia solid electrolyte galvanic cell technique to assess the reliability of the activity values obtained by the mass spectrometric method.

Although the activities of nickel obtained by the emf measurements showed slightly lower values over the entire composition range than those obtained by the mass spectrometry, both results agreed fairly well and exhibited negative deviations from Raoult's law. The activity coefficients of nickel and palladium at infinite dilution at $1833 \mathrm{~K}$ were calculated as $\gamma_{\mathrm{Ni}}^{\circ}=0.188$ and $\gamma_{\mathrm{Pd}}^{\circ}=0.367$.

\section{Acknowledgement}

The authors wish to thank Mr. Y. Fujiwara for performance of a part of the emf measurements.

\section{REFERENCES}

(1) G. R. Belton and R. J. Fruehan: J. Phys. Chem., 71 (1967), 1403.

(2) K. Ono, S. Nishi and T. Oishi: Trans. JIM, 25 (1984), 810 .

(3) A. I. Timofeev, N. A. Vatolin, O. A. Esin and E. L. Dubinin: Tr. Sverdlovsk. Met. Inst., 20 (1969), 120.

(4) L. R. Bidwell and R. Speiser: Acta Met., 13 (1965), 61.

(5) N. Kemori, I. Katayama and Z. Kozuka: J. Chem. Thermodyn., 13 (1981), 313.

(6) H. A. Wriedt and J. Chipman: Trans. AIME, 203 (1955), 477. 